\title{
Homosexual Orientation in Marriage: A Reason for Divorce?
}

\author{
Donny Chrissutianto \\ Adventist International Institute of Advanced Studies \\ chrissutiantod@aiias.edu
}

\begin{abstract}
The number of homosexuals in Seventh Day Adventist Church has increased since 1980. It becomes a problem for the church until it was discussed and decided that this practice may as a reason for divorce. However, there is no hint if the case is homosexual in practice. If there is a problem in a newly couple that just married and in the very day one spouse says that he or she has the homosexual orientation what should be done with this couple. Is this confessing could be used as a reason for divorce? There should be a solution for the couple to handle this problem. The Bible clearly rejected homosexuality practices. To help the couple who has problem with homosexuality orientation in marriage, the principles of Bible and Spirit of prophecy should be utilized. This article attempts to expose these principles and helps to restore the proper sexual orientation that a couple should have in marriage.
\end{abstract}

Keywords: homosexual; divorce; marriage; sexual orientation

\section{Introduction}

Homosexuality is a common practice in this world, and its adherents have got many challenges in the Christian Community. ${ }^{1}$ In 1980s, there were ten thousand to twenty thousand homosexuals in the Seventh Day Adventist Church only in the United States, ${ }^{2}$ but now they are around $3 \%$ of the membership in the country are identified as homosexual orientation. ${ }^{3}$ This phenomenon is increasing year after year but there is lacking of efforts to deal with it. ${ }^{4}$

The problem discussed in this paper is if church members involve in the homosexual orientation while they are in marriage, what does suppose the reaction of the church. Seventh Day Adventist's Church Manual only deals with the homosexual practicing and not homosexual orientation as it states about "sexual perversions, including incest, child sexual abuse, and homosexual practices, are also recognized as a misuse of sexual powers and a violation of the divine intention in marriage. As such they are just cause for separation or divorce." ${ }^{5}$ In this

1 Michael D. Pearson, "Seventh Day Adventist Responses to Some Contemporary Ethical Problems,"

Doctor of Philosophy Dissertation, Oxford University,1986, p. 278.

2 Insight, "The Church's responsibility to Homosexuals," December 16, 1980, 9.

${ }^{3}$ Carrol J. Grady, Survey Explores Attitudes Toward Homosexuality Among Adventists," Adventist Today, (May 23, 2013), http://www.atoday.org/article/1862/news/may/survey-explores-attitudes-toward-homosexualityamong-adventists?search=Homosexuality+in+Adventists (accesed Oct 21, 2013).

4 Insight, Dec 16, 1980, 9.

${ }^{5}$ Secretariat General Conference of Seventh-Day Adventist, Seventh-Day Adventist Church Manual (SDACM), (Maryland, Hagerstown: Review and Herald, 2010),152. 
statement, homosexual practices can be used as the reason for divorce even though the first attempt to deal with it is reconciliation between the husband and the wife. ${ }^{6}$

The Church Manual only covers problems about homosexual practices but it does not deal with homosexual orientation in marriage. If there is a problem in a newly married couple that one of them confesses having homosexual orientation, what should be done with this couple. Is this confession can be used as a reason for divorce? This paper seeks to give suggestion to handle this issue. In order to accomplish this purpose, exploring the origin of sexual activities, homosexual and divorce in the Bible and Ellen G. White writings enlighten this study.

\section{The Origin of Sexual Acts}

The first hint regarding the sexual activity in the Bible was in the creation account. In the sixth day when God created Adam and Eve, He blessed and said to them "be fruitful and increase in number" (Gen 1:28). This command is fulfilled only by sexual activity. In this verse, the sexual activity between Adam and Eve was implied in the context of marriage. It is important to note that the first sexual activity was done in marriage between male and female after receiving a blessing from God.

The first explicit notion about the sexual activity in the Bible is in Genesis 4:1. The bible says, "Adam lay with his wife Eve, and she became pregnant and gave birth to Cain" (NIV). The word "lay" in this verse comes from the word י (yada) which means "knowing" yet this word is "a common idiom for sexual relations in the Old Testament." 7 The word also appears in Genesis 19:5 in the case of the two angels who were as guests of Lot. The people of Sodom says "where are the men who came to you tonight? Bring them out to us so that we can have sex with them" (NIV). The word that was used in term "have sex" is the same word (yada) that referring to the word "lay" (NIV), "had relation" (NASB) or "knew" (NKJV) in Genesis 4:1. Therefore yada in the context of Genesis 4:1 refers to the intimate relationship between husband and wife and it was applied in sexual activities which resulted a descendant. This sexual activity was done in an institution that God has established in Eden because Adam did it "with his wife." In the origin God created the sexual activities exclusively between man and woman in marriage. The practice of homosexuality came later on as a perversion behavior of humanity after the fall.

\section{Homosexuality in the Old Testament}

Homosexual practices records exist in the Old Testament. Some of the Pentateuch and historical books indicate the perversion of this sexual activities.

\section{Pentateuch}

The story of the destruction of Sodom and Gomorrah points out that homosexuality was one of the sins performed by the population in these two cities. When Lot insisted the unknown persons to come to his house and served them, before they slept, the Bible says "the men of the city, the men of Sodom, surrounded the house, both young and old, all the people from every

6 Ibid.

${ }^{7}$ K. A. Mathews, Genesis, The New American Commentary (NAC) 1A (Nashville: Broadman \& Holman Publishers, 2001), 264. 
quarter" (Gen 19:4, NASB). The word that used for "the men", "the men of Sodom", "young and old," and "people" in this verse are in masculine form and in the verse 5 stated, "Where are the men who came to you tonight? Bring them out to us that we may have relations with them." The word "men" in the verse indicates to the masculine form and the words "have relations" to the angels derived from the word yada that have been discussed earlier which indicate to have sexual activity. This is the first text in the Bible that may refer to the homosexual action.

The homosexuality in the city of Sodom was one of the sins leading to the destruction of Sodom. ${ }^{8}$ It was not just practiced by some of men but many who lived in it. The first appearance of homosexual activity in the bible is in negative impression and made the city disappeared. The same sex activity "called sodomy, after Sodom, that wicked city which was destroyed on account of this perversity." "

The other hint of homosexuality in Pentateuch is about an explicit prohibition of homosexuality. "You shall not lie with a male as with a woman; it is an abomination" (Lev 18:22, RSV). This verse means, all together with the following verses, the prohibition of the Israelites to have homosexual practice among them and need to teach this command to their descendants. It is one of the clearest commands from the Lord to distinguish themselves from the local nations (verse 27). This practice was detestable in the presence of God, said Moses. The transgressor would have a capital punishment (verse 27-29).

Another text of Homosexuality in the writings of Moses is in Leviticus 20:13. Moses wrote, "if there is a man who lies with a male as those who lie with a woman, both of them have committed a detestable act; they shall surely be put to death. Their blood guiltiness is upon them" (NASB). This verse explains explicitly about the "male homosexuality" and its punishment. This capital punishment indicated that homosexuality is a detestable thing before God. This text is a reiteration of 18:22, yet, accompanied by the direct punishment to the specific sin. ${ }^{10}$

The same law about homosexuality is in Deuteronomy 23:17, 18. God distinctly commanded:

None of the daughters of Israel shall be a cult prostitute, nor shall any of the sons of Israel be a cult prostitute. ${ }^{18}$ "You shall not bring the hire of a harlot or the wages of a dog into the house of the LORD your God for any votive offering, for both of these are an abomination to the LORD your God.

These texts show how the practice of homosexuality, for both women and men, was common "in the worship of the Canaanitish Astarte." 11 The term "wages of a dog" indicates the practice of homosexuality. ${ }^{12}$ In verse 17 , the Hebrew word of "the kedeshah is a prostitute, perhaps the kadesh here is a male prostitute, either heterosexual or homosexual." 13 The male prostitute in this text seems not just giving themselves to the women but also to the men. The female and male prostitution were condemned by God and He mentioned those practices as abhorrent things.

${ }^{8}$ Carl Friedrich Keil and Franz Delitzsch, Commentary on the Old Testament. (Peabody, MA: Hendrickson, 2002), 1:149.

9 Norman L. Geisler, Ethics: Alternatives and Issues, (Grand Rapids, MI: Zondervan 1971), 203.

${ }^{10}$ John E. Hartley, Leviticus, Word Biblical Commentary (Dallas: Word, Incorporated, 2002), 339.

${ }^{11}$ Carl Friedrich Keil and Franz Delitzsch, COT, 1:949.

12 "The wages of a dog: money earned by a male temple prostitute. RSV footnote provides "sodomite" as an alternative rendering of dog. The context is that of temple prostitution." Robert G. Bratcher and Howard Hatton, $A$ Handbook on Deuteronomy, UBS handbook series (New York: United Bible Societies, 2000), 389.

${ }^{13}$ Jeffrey H. Tigay, Deuteronomy, The JPS Torah commentary (Philadelphia: Jewish Publication Society, 1996), 216. 


\section{Book of Judges}

A narrative about a Levite who travelling from Bethlehem Judea to the hill country of Ephraim in Judge 19 is another indication of homosexual practices among Israelites. When he and his concubine travelled back to his home town, an old man offered to stay overnight at his house (Judges 19:16-21). When they were in the house, "some of the wicked men of the city surrounded the house. Pounding on the door, they shouted to the old man who owned the house, "Bring out the man who came to your house so we can have sex with him" (Jdg 19:22 NIV). The words "have sex" have the same word used in Gen 19:5, yada, it means sexual intercourse. ${ }^{14}$ Other expressions, such as "wicked men" and "they," show the masculine plural form in Hebrew. It shows that the men in the city asked the host, the old man, to hand over the guest who was a man in order they could have sex with him. It indicated that the people in that town practiced homosexuality. ${ }^{15}$ Even though this practice did not happen, however, another immorality performed and led to the destruction of the place in chapter 20. God answered the inquiry of the Israelites to destroy the town may indicate His disagreement to the immorality which was happening including the "homosexual orientation." "God performs his consistency to prohibit those who practice the immorality and sexual perversion.

\section{Historical Book}

At the times of Rehoboam and his successors, the practice of homosexuality appeared widely among the Israelites. The Bible says "there were also male cult prostitutes in the land. They did according to all the abominations of the nations which the LORD dispossessed before the sons of Israel" (1 Kings 14:24). The words "male cult prostitutes" are translated in King James Version as "sodomites" who refers to the event in Genesis 19 where God destructed the city of Sodom because of their immorality and sexual perversion. These words came from the word qadesh which could refer to homosexual practices. ${ }^{17}$ This term, qadesh, is a common practice in Canaanites as a part of worship to their goddess. ${ }^{18}$ This perverting action happened in the times of Rehoboam and he did not do anything to abolish this influence. This caused God handed over the nation into the king of Egypt (1 kings 14:25,26). The immorality of Israel included the qadesh made God left them and it was always repeated in the history of Israel.

When Asa reigned over Judah, he made a reformation in the land of Judah. One of his action was, he destroyed all the qadesh (1 Kings 15:12). In this verse, the word appears in the

${ }^{14}$ Daniel Isaac Block, vol. 6, Judges, Ruth, The New American Commentary (Nashville: Broadman \& Holman Publishers, 2001), 536.

15 Ibid.

16 Ibid.

17،Among the various pagan religious practices condoned in Judah was male homosexual prostitution. Such practice stands universally condemned in Scripture as the ultimate distortion of mind and nature (cf. Lev. 18:22; 20:13; Rom. 1:24-32; 1 Cor. 6:9)." Believer's Study Bible, Criswell Center for Biblical Studies (Nashville: Thomas Nelson 1991), 1 Ki 14:24. See also John F. Walvoord, Roy B. Zuck and Dallas Theological Seminary, The Bible Knowledge Commentary: An Exposition of the Scriptures (Wheaton, IL: Victor Books, 1983), 1:517-518. Matthew Henry, Matthew Henry's Commentary on the Whole Bible: Complete and Unabridged in One Volume (Peabody: Hendrickson, 1996), 1 Ki 14:21. "Sodomites" [1 kings 14:24], The Seventh-day Adventist Bible Commentary, rev.ed, ed. Francis D. Nichol, (Review and Herald Publishing Association, 1978), 2: 801.

${ }^{18}$ Paul R. House, 1, 2 Kings, New American Commentary (Nashville: Broadman \& Holman Publishers, 1995), 8:194. 
plural form while in 14:24, it emerges in the singular form. He believed this annihilation agreed with the will of God (15:11). The Bible testifies that Asa did "right in the eyes of the Lord."

In the time of Jehoshaphat, the son of Asa, eliminated the qadesh which remained in the time of his father (22:47). In this text, the NASB does not translate the word as "male cult prostitutes" similar with 14:24 and 15:12 but translated it as "sodomites." Even though it seems that the translation is not consistent, however, it implies that the sodomites refer to the same meaning with the "male cult prostitutes." These English translations, NASB and KJV, consider that the word qadesh means sodomites. Homosexuality, in this text, was a detestable thing for God.

King Josiah made a reformation when he reigned as the king of Judah. The scripture says that "he also broke down the houses of the male cult prostitutes which were in the house of the LORD, where the women were weaving hangings for the Asherah" (2 Kings 23:7). The word "male cult prostitutes" in this text came from the Hebrew word qedeshim that refers to "all kinds of prostitutes"19 including homosexuals or "sodomites." 20 Josiah fought this practice and attempted to reform the worship in the land of Judah and also syncretism which has been practiced for many years.

Therefore, historical books indicate several proofs of homosexuality tendency and practices among the Israelites. God prohibited this practice and allowed the elimination of those who involved in it.

\section{Homosexuality in the New Testament}

Homosexuality also exists in the New Testament. This practice has been accepted by other nations. Paul's letters and General Epistles indicate the existence of homosexuality.

\section{Epistle of Paul}

In the writing of Paul, homosexual practices existed and he commented that this was as an unnatural passion (Romans 1:26, 27). Severian noted "Paul did not say this lightly, but because he had heard that there was a homosexual community at Rome." ${ }^{21}$ It did not just the practice occurred but also the homosexuality community existed in the first century especially in Rome. The two practices, those are "lesbianists" and "pederastists" were condemned by Paul 22 and warned those people would receive their "penalty."

Paul wrote to Corinthians to against homosexuality. He stated, "that the unrighteous will not inherit the kingdom of God? Do not be deceived; neither fornicators, nor idolaters, nor adulterers, nor effeminate, nor homosexuals" (1Corinthians 6:9). The word that Paul uses to

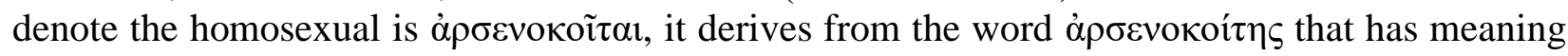

\footnotetext{
${ }^{19}$ Adam Clarke, Clarke's Commentary: Second Kings, Clarke's Commentaries (Albany, OR: Ages Software, 1999), 2 Ki 23:7.

${ }^{20}$ William MacDonald and Arthur Farstad, Believer's Bible Commentary: Old and New Testaments (Nashville: Thomas Nelson, 1995), 2 Ki 23:4.

${ }^{21}$ Gerald Lewis Bray, Romans, Ancient Christian Commentary on Scripture NT 6. (Downers Grove, IL: InterVarsity Press, 1998), 47.

${ }^{22}$ William Hendriksen and Simon J. Kistemaker, New Testament Commentary: Exposition of Paul's Epistle to the Romans, New Testament Commentary (Grand Rapids: Baker Book House, 1953), 78.
} 
as "homosexual, sodomite" and pederast. ${ }^{23}$ Paul categorized this practice as a sin and those who practice it will do not "inherit the kingdom of God" (verse 10).

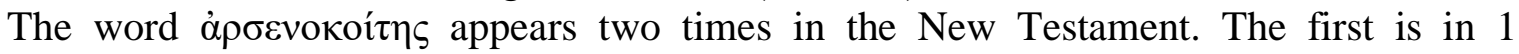
Corinthians 6:9 and the second is in the 1 Timothy 1:10. Paul classified the "immoral men and homosexuals and kidnappers and liars and perjurers, and whatever else is contrary to sound

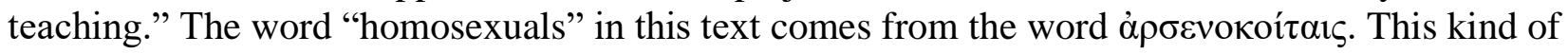
sin has the same quality with the others which are called as "lawless" and "sinners" (verse 9). Paul's writings are against the practice of homosexuality.

\section{General Epistle}

In the book of Jude, the notion about homosexual practices appears and it correlates to the destruction of Sodom and Gomorrah. The Bible says:

Just as Sodom and Gomorrah and the cities around them, since they in the same way as these indulged in gross immorality and went after strange flesh, are exhibited as an example in undergoing the punishment of eternal fire. Yet in the same way these men, also by dreaming, defile the flesh, and reject authority, and revile angelic majesties. (Jud 1:7-8)

In these texts, the word "these men" refers to the masculine form and these persons "defiled their flesh" showed the "homosexual acts." 24 The result of this action was the eternal fire came upon those who did this kind of perversion (verse 7).

In the last book of New Testament, there was also an indication about homosexual practices. Jesus says to John the Apostle about those who live outside the New Jerusalem "are the dogs and the sorcerers and the immoral persons and the murderers and the idolaters, and everyone who loves and practices lying" (Revelation 22:15). The word "dogs" may refer to "a male prostitute ... (Deut. 23:18)" "25 or "homosexual."26 The "dogs" lived outside the New Jerusalem means that they will not be received in the new earth which God will create for His people.

Thus, the Bible is consistent against homosexual practices and its tendencies. He never changed His principles to keep the Christian standard for His people. As this writing relates to divorce, the following section discusses about divorce in the Scriptures.

\section{Divorce in Old Testament}

There are some hints about divorce in the bible. The first hint is in Pentateuch. In Deuteronomy 24:1-2, Moses noted that husband could give a letter of divorce to the wife if she

${ }^{23}$ Max Zerwick and Mary Grosvenor, A Grammatical Analysis of the Greek New Testament, Originally Published Under Title: Analysis Philologica Novi Testamenti Graeci; Translated, Revised and Adapted by Mary Grosvenor in Collaboration With the Author. (Rome: Biblical Institute Press, 1974), 508.

${ }^{24}$ Earl D. Radmacher, Ronald Barclay Allen and H. Wayne House, Nelson's New Illustrated Bible Commentary (Nashville: T. Nelson Publishers, 1999), Jud 7.

${ }^{25}$ Simon J. Kistemaker and William Hendriksen, New Testament Commentary: Exposition of the Book of Revelation, New Testament Commentary (Grand Rapids: Baker Book House, 1953), $20: 591$.

26 "It may be that $\kappa v ́ \omega v$, ' $d o g$ '... is used more specifically here for male homosexuals, pederasts, or sodomites since the term on the parallel vice list in 21:8." David E. Aune, Word Biblical Commentary: Revelation 17-22, (Dallas: Word, Incorporated, 2002), 1222. 
had "no favor in his eyes." Moses did it might be caused "the practice of divorces was at this early period very prevalent amongst the Israelites, who had in all probability become familiar with it in Egypt."27 To this letter of divorce, Jesus says "because of your hardness of heart Moses permitted you to divorce your wives; but from the beginning it has not been this way" (Matt 19:8). God intended since the beginning that there should not be divorce in marriage. The stiff neck of the Israelites made Moses permitted it.

In the book of Jeremiah, there are some accounts about divorce. It happened between God and his people who symbolized that God was as the husband and His people were the wife. God gave the letter of divorce to Israel because they had betrayed Him (Jeremiah 3:8). But God did not cease to this point, He asked them to come back to him. He wanted to renew his covenant to His "unfaithful wife" (verse 14, 22). Through this account, it seems that the divorce may happen if there is one spouse betrays their marriage through adultery. But even though the unfaithfullness is a hurtful thing for the faithful one, as God did, the faithful needs to forgive the unfaithful. ${ }^{28}$ It was the point that God wants to emphasize to His people regarding marriage.

In the last book of Old Testament, once again, God gives His explicit notion about divorce. He said, "For I hate divorce" (Malachi 2:16). This statement agrees with what Jesus says in Matthew 19:8. Moreover, He stressed twice for the men to "do not break faith" to their youth wife $(2: 15,16)$. God was not favorable on divorce, even though it is permissible in certain cases.

\section{Divorce in New Testament}

The book of Matthew deals with divorce directly. This is based upon the comment of Jesus to the audience in the Sermon on the Mount. He says, "I say to you that everyone who divorces his wife, except for the reason of unchastity, makes her commit adultery; and whoever marries a divorced woman commits adultery" (Mat 5:32). The word that translated as "unchastity" comes from the Greek word ropveías. The meaning of the word is the sexual unfaithfulness of a married woman. ${ }^{29}$ This word prevented the Jews to divorce their wives for any reason and at the same time to protect women from their irresponsible husband.

The same reason was given by Jesus when someone asked him about the statement of Moses who allowed them to give a certificate of divorce. He argues, "I say to you, whoever divorces his wife, except for immorality, and marries another woman commits adultery" (Mat 19:9). The Greek word that used for "immorality" was $\pi$ opveía. This word has the same root

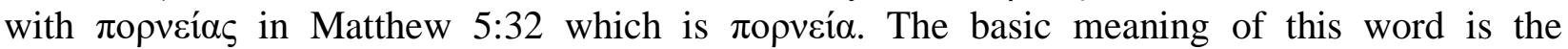
extramarital sexual activity. ${ }^{30}$

Another reason for divorce could be seen from the writings of Paul. He wrote, "Yet if the unbelieving one leaves, let him leave; the brother or the sister is not under bondage in such cases, but God has called us to peace" (1Co 7:15). The word that is translated as "leaves" comes from

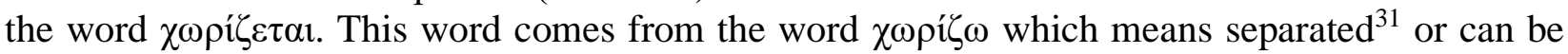

${ }^{27}$ Robert Jamieson, A. R. Fausset, A. R. Fausset et al., A Commentary, Critical and Explanatory, on the Old and New Testaments, On Spine: Critical and Explanatory Commentary. (Oak Harbor, WA: Logos Research Systems, Inc., 1997), Dt 24:1.

28 The whole book of Hosea showed the forgiveness that God has given to the unfaithful one.

${ }^{29}$ Max Zerwick and Mary Grosvenor, A Grammatical Analysis of the Greek New Testament (GAGNT), 13.

${ }^{30}$ Ibid.

31 Ibid. 
translated as "divorce." 32 The New Testament gave two reasons why someone may divorce. The first is because the extra marital sexual act and the second if the unbeliever wants to leave his/her spouse. In this way, Paul is not favorable for divorce. The following sections examine the writings of Ellen G. White about homosexuality and divorce.

\section{Homosexuality in E.G. White writings}

There was no explicit hint about homosexuality in the writings of Ellen White. ${ }^{33}$ Regarding the sins in Sodom and Gomorrah, "she would have regarded it as one among the many sins of a thoroughly decadent society" 34 but she did not mention it explicitly, may be because sexuality was a taboo to discuss at that time. ${ }^{35}$ Yet, there are some expressions that she utilized to indicate the sins of Sodom in Genesis 19. She told the sins of Sodom as "deface the image of God" 36 and the destruction of Sodom was caused "by the vilest passions" 37 of the inhabitant. In another occasion, she wrote the sins as the "gratification of unnatural appetite," 38 it seems like similar terms that used by Paul in Romans 1: 26 when he talked about the homosexual sin. In this text Paul used the words "vile" and "unnatural" to describe the homosexual action. There was a possibility that Mrs White might refer to this practice but in the polite words. The most explicit words that Mrs White used to describe homosexuality is in the case of Lot and his guests. The men in Sodom "would have abused the men...were entertained by Lot." 39 The word "abused the men" would be done by the inhabitant of Sodom may signify the homosexual practice in that city. ${ }^{40}$

Pertaining the sins of Sodom and Gomorrah, that the book of Jude cites, Ellen G. White mentioned it as a sin of the community since they entertained and cherished it. She wrote:

These are the very sins which corrupted Sodom. Their evil practices did not come all at once. First one man and woman stupefied themselves by unholy, polluted habits. Then as inhabitants settled in Sodom, they did as you are doing, educating others in a line that is forbidden of God. And so as the inhabitants continued to multiply, these ministers of sin continued in educating them in their own defiling practices until if any person came into their midst their first thoughts were to educate them in their evil work, until Sodom became renowned for its pollutions. Their sins reached unto heaven, and the Lord would bear with them no longer. He destroyed them and all that was beautiful, that made it as a second Eden, for the earth was defiled under the inhabitants thereof. ${ }^{41}$

\footnotetext{
${ }^{32}$ Archibald Robertson and Alfred Plummer, A Critical and Exegetical Commentary on the First Epistle of St. Paul to the Corinthians, (New York: C. Scribner's Sons, 1911), 143.

${ }^{33}$ A L White letter, 26 August 1974 in Michael D. Pearson, "Seventh Day Adventist Responses to Some Contemporary Ethical Problems" (PhD Dissertation, Oxford University, 1986), 290.

34 The word "it" in the sentence means the sin of homosexuality. Pearson, "Seventh Day Adventist Responses," 291.

35 Ibid.

${ }^{36}$ Ellen Gould White, Patriarchs and Prophets, (Mountain View, California: Pacific press, 1890), 156.

37 Ibid, 159.

${ }^{38}$ Ellen Gould White, Counsels on Health, (Mountain View, California: Pacific press, 1923), 110.

${ }^{39}$ Ellen G. White, Manuscript 19a, 1886.

${ }^{40}$ Pearson, "Seventh Day Adventist Responses," 290.

${ }^{41}$ Ellen G. White, Testimonies on Sexual Behavior, Adultery, and Divorce, (Ellen G. White Estate, 1989),
} 126. 
In these statements, she did not emphasize on what kind of sin happening in the city of Sodom but rather to how did the city become so wicked until "their sins reached unto heaven." She just said about the "evil practices" that the inhabitant did and called them as "ministers of sin" without mentioning the sins.

Another comment of Ellen G. White in 1 Timothy 1:9, 10 indicates about homosexuality. The list of sins in this text was defecting their character and led to the "moral deformity." 42 The sins, where the homosexuality implied, according to her, aborted the development of Christ's characters in Christians' lives.

Ellen White did not mention the homosexual practices explicitly when she discussed about this practice. She commented about "the male shrine prostitutes" in 1 Kings 22:46 as the cause of "many of perils that had been threatening to retard seriously their spiritual development." 43 The main focus of her in this text is she did not agree with the sexual perversion among the Israelites. She supported what the king of Israel did to restore the true worship to the true God.

\section{Divorce in E.G. White writings}

Ellen G. White, the same with the position of the Bible, disagrees that divorce could happen without adultery reason. She was fully supportive to what Jesus says in the Matthew 19:9. She notes that "there could be no dissolution of the marriage tie except for unfaithfulness to the marriage vow." 44 In another case, to the one whom contemplating for divorce, she advised "your ideas in regard to the marriage relation have been erroneous. Nothing but the violation of the marriage bed can either break or annul the marriage vow." 45 To a sister who looking for a divorce, she penned "if she, or any other woman, should obtain a divorce legally on the ground that her husband was guilty of adultery, then she is free to be married to whom she chooses." 46 In the case of there is an adultery in a marriage, the faithful spouse may propose a divorce.

The second reason of divorce in the writings of Mrs White appeared in her counsel about the unbeliever wife. She wrote:

If the wife is an unbeliever and an opposer, the husband cannot, in view of the law of God, put her away on this ground alone. In order to be in harmony with the law of Jehovah, he must abide with her unless she chooses of herself to depart. He may suffer opposition and be oppressed and annoyed in many ways; he will find his comfort and his strength and support from God, who is able to give grace for every emergency. ${ }^{47}$

The words "unless she chooses of herself to depart" seem relevant to 1 Corinthians 7:15 in which Paul says that it did "not under bondage" to separate. In different but similar situation Ellen White explained clearly about a marriage and divorce:

I cannot see that this new union should be disturbed. It is a serious matter to part a man and his wife. There is no scriptural ground upon which to take such a step in this case. He did not leave her, she left him. He did not marry again until she had obtained a divorce...I

\footnotetext{
${ }^{42}$ Ellen White, Review and Herald, March 8, 1870.

${ }^{43}$ Ellen White, Prophets and Kings, (Mountain View, California: Pacific press, 1917), 192.

${ }^{44}$ Ellen White, Adventist Home, (Nashville, TN: Southern Publishing Association, 1952), 341.

45 Ibid, 342.

46 Ibid, 345.

47 Ibid.
} 
see nothing in the Word of God that would require her to separate from him. As you have asked my advice I will freely give it to you. ${ }^{48}$

This statement confirms what Paul said about faithful Christians who abandoned by unbeliever spouse in order to have a lawful marriage.

\section{Applying biblical concepts to the case}

The Seventh-day Adventist Church Manual deals only to those who engage in homosexual practices and they may "cause for separation or divorce" 49 without alluding the case of homosexual orientation. The one who practice homosexuality, psychologically, may be caused by one of these three reasons. The first is that this man may have bad experience with his father or has no positive image of a father in his life. On another hand, the mother was so dominant in his life. ${ }^{50}$ Second is children could not pass smoothly their transition period from childhood to become teenager or even adulthood. It means children should have trustable person to guide them in this process. ${ }^{51}$ Third is who is introducing sex to the children. This is very important because "if he was introduced to sex with a male who enjoyed it, that may contribute toward a homosexual orientation." ${ }^{52}$ That is why there is a strong indication that homosexual is learned and not natural. ${ }^{53}$ To deal with this case, someone should be "kindness and love even as they would treat patients in a hospital." 54

The biblical approaches will help the one who has homosexual orientation in marriage. The first is as the spouses know about this orientation and need to forgive their husband or wives for their weaknesses. The Bible says about Hosea who forgave his wife who had committed adultery (Hosea 3:1-3). This first step is always suggested to in the adultery case. ${ }^{55}$ Moreover to the case of homosexual orientation which the practice is not yet happened, even though, the symptoms are known, forgiveness is very vital.

The second step is the "normal spouses" needs to know the background why their partners have the homosexual orientation and willingness to help them. This will aid the homosexual tendency to overcome their inclination. The Bible says "two are better than one because they have a good return for their labor" (Ecc 4:9). In the same book (4:12) Solomon says "if one can overpower him who is alone, two can resist him." If the normal spouses support the homosexual tendency partners by showing their acceptance, forgiveness and love, a chance to overcome this inclination is bigger.

The other principle that can be applied is redemptive actions. In this step, the principle that Paul says in 1 Corinthians 7:12-14 in which the believer spouse could sanctify the unbeliever spouse. The homosexual tendency of a husband or wife can be overcome by the holiness life showed by the "normal spouses." The patient, faith and love of the normal spouses will help these people to overcome this tendency. If it prevailed in the past, it prevails now.

\footnotetext{
${ }^{48}$ Ellen White, Selected Messages book (Washington, DC: Review and Herald, 1958), 2:341.

${ }^{49}$ Secretariat General Conference of Seventh-Day Adventist, SDACM, 152.

${ }^{50}$ Scott B. Rae, Moral Choices: An Introduction to Ethics (Grand Rapids, MI: Zondervan, 2009), 281.

51 Ibid.

52 Ibid.

53 Ibid.

${ }^{54}$ K.H. Wood, "Power to counter all deviations", Review, July 15 1971, 2.

55 Secretariat General Conference of Seventh-Day Adventist, SDACM, 152.
} 


\section{Applying Ellen G. White Concepts to the case}

In her writings, Ellen White recognized the weaknesses of human characters and counseled to every couple to accept their spouses as they are. She advises "when you made your vow before God and holy angels, you knew you were not perfect and your husband was not perfect; but this is no excuse for breaking your marriage vow. There is a need of training your mind and heart that you shall bear with one another, to be kind to one another, and not to allow distrust and hatred to come in." 56 To apply this principle, first is to receive the condition of the homosexual or "disoriented spouses" as they are. They should face together by the grace of God.

The second principle in dealing to this case is to guide the "disoriented spouses" to Jesus. There is no other power can help in this case except both of them come and ask the power of Holy Spirit. Ellen White said "Christ has given His Spirit as a divine power to overcome all hereditary and cultivated tendencies to evil, and to impress His own character upon His Church., ${ }^{57}$ This defected character even though some people think as "inherited" 58 but still can be defeated by Jesus' power.

The third principle in dealing to this problem is to show our loving spirit. To those who feel that their weaknesses are inherited, she writes, "let Christians, then, continue to hold moral standards high. Let them call sin by its right name. At the same time let them point to the allpowerful Christ as the One who can meet every need, and let them reflect His warm understanding, loving spirit to every repentant sinner, whether his problem be inherited or cultivated." 59 Dealing to such case, they do not need too much preaching and teaching but the sympathy and love of Jesus then instruction. Words of sympathy and action of love will encourage to their restoration.

\section{Conclusion}

The Bible and Ellen White writings did not agree to the practice of homosexuality even though in her writings, she just mentioned it implicitly. The Scripture condemned those who practice homosexuality to the death sentence since it could bring God's people into a deep apostasy and suffered the judgment of God.

To dealing with those who have homosexual orientation in marriage, the Seventh-day Adventist Church Manual cannot be applied. The Church Manual deals only to the homosexual practices but not to homosexual orientation. Yet, the wise approach must be applied to help them in overcoming this challenge.

In this case, the first thing is that the "normal spouses" need to forgive the homosexual tendency or "disoriented spouses" and realize that "the normal spouses" also have other weakness that their partners have to understand. The second is the normal spouses are willing to support their "disoriented spouses" and lead them to the power of Jesus who can overcome their pervert tendency. In doing this, the normal spouses play an important role to help their partners. The last thing but not the least is the "normal spouses" have to show the love of Jesus is living in their

${ }^{56}$ Ellen G. White, Testimonies on the sexual behavior, Adultery, and Divorce (The trustees of the Ellen G. White Estate, 1989), 56.

${ }^{57}$ Ellen White, Desire of Ages, (Washington DC: Review and Herald, 1898), 671.

${ }^{58}$ Norman L. Geisler, Christian Ethics: Contemporaries Issues and Options (Grand Rapids, MI: Baker Academic, 2010), 283.

${ }^{59}$ Ellen White, Review, July 15 1971, 2. 
lives; in order to attract their "disoriented partners" to Jesus. These steps are called the redemptive efforts following what Jesus did and taught to His church.

Therefore, if there is a spouse who has homosexual orientation in marriage, is it a reason for divorce? On one side, as far as the person has a willingness to change his/her orientation by the grace of God, and they want to live with his/her "normal spouse"; and on other side there are an acceptance, forgiveness and love at the part of the "normal spouse," there is no reason for divorce.

\section{Suggestions to Prevent the Case}

Before marriage, the pre-marital counseling is very crucial. This is the first prevention to know the background of each person who wants to engage in marriage. It may help the couple to know better the person who will be their spouse. The second is the marriage counselor should advice the ones who want to engage in marriage to pay attention to the sexual tendency that each person has so that this case should not happen in marriage. The third is a lot of prayer. God will show who is the best spouse for each one of them. There is no other more powerful way to prepare a marriage than submits all the planning into God's hand. 